\title{
PENGARUH KEBIJAKAN HARGA ECERAN TERTINGGI (HET) BERAS TERHADAP LAJU INFLASI BERAS DI SULAWESI SELATAN
}

\author{
Rice Price Ceiling (HET) Regulation's Effect Toward Rice's Inflation Rate in South Sulawesi \\ Andi Tiara Putri, Rahim Darma*, Letty Fudjaja \\ Program Studi Agribisnis, Departemen Sosial Ekonomi Pertanian, \\ Fakultas Pertanian, Universitas Hasanuddin, Makassar \\ *Kontak penulis: tiaraputri.marasanti@yahoo.com
}

\begin{abstract}
This study aims to analyze the rice ceiling price's effect among the rice retailers released by The Trade Minister on September 2017 toward inflation rate, especially in South Sulawesi. Using three cities that will represent South Sulawesi's rice inflation rate as a whole, those cities are Kota Makassar, Kota Pare-pare and Kabupaten Bone. Variables that used are rice stock, rice price margin, real exchange rate, and rice's inflation rate from each region were calculated using the Ordinary Least Square (OLS) method. Data series were taken month-to-month, start from April 2016 to December 2018. In conclusion, the policy positively increases the rice's inflation rate since its first implementation. It has proven by 4 of 6 equations, explained by its dummy variables. Hence, the government should re-evaluate this policy so the inflation rate can preserve below the yearly inflation target.
\end{abstract}

Keywords: ceiling price; rice price regulation; rice inflation.

\begin{abstract}
Abstrak
Penelitian ini bertujuan untuk menganalisis kebijakan harga eceran tertinggi untuk pengecer beras yang dirilis oleh Menteri Perdagangan pada September 2017 terhadap laju inflasi beras, terutama di Provinsi Sulawesi Selatan. Penelitian ini menggunakan tiga kota yang dianggap mewakili Sulawesi Selatan dalam menghitung laju inflasi: Kota Makassar, Kota Pare-pare dan Kabupaten Bone. Semua variabel dianalisa menggunakan Regresi Linier Berganda. Variabel-variabel tersebut adalah stok beras, margin harga beras, nilai tukar riil, dan tingkat inflasi dari masing-masing daerah. Data diambil dari April 2016 hingga Desember 2018 dan menggunakan estimasi month-to-month. Kesimpulannya, kebijakan tersebut secara positif meningkatkan laju inflasi. Hal tersebut dibuktikan oleh 4 dari 6 persamaan yang secara harfiah dijelaskan oleh nilai variabel dummy tiap persamaan. Oleh karena itu, pemerintah harus mengevaluasi kembali kebijakan ini sehingga tingkat inflasi dapat dipertahankan di bawah target inflasi tahunan.
\end{abstract}

Kata Kunci: harga eceran tertinggi; kebijakan harga beras; inflasi beras.

\section{Pendahuluan}

Inflasi merupakan fenomena ekonomi yang masih menjadi fokus pemerintah di Indonesia saat ini. Target inflasi yang ditetapkan oleh pemerintah tidak lepas dari tujuan pemerintah dalam menjadi kestabilan ekonomi di Indonesia. Laju inflasi disebabkan oleh beberapa faktor, salah satunya adalah harga beras. Harga beras berpengaruh karena beras 
masih menjadi komoditas utama pertanian dan makanan pokok masyarakat Indonesia (Abdullah, 2017). Berdasarkan data yang dikeluarkan oleh Badan Pusat Statistik (2017), konsumsi masyarakat Indonesia terhadap beras mencapai 114,6 kg per kapita per tahun.

Harga beras bersifat inelastis. Hal ini yang menyebabkan komoditas tersebut rentan terkena inflasi. Selain karena jumlah konsumsi per kapita per tahun, pasokan beras biasanya sering mengalami gangguan terutama disebabkan oleh cuaca yang tidak menentu. Bentuk upaya pemerintah untuk mewujudkan stabilitas harga beras adalah dengan menerapkan instrumen kebijakan harga yang mengatur harga dasar (floor price) dan harga maksimum (ceiling price). Kebijakan harga dasar diatur pada kebijakan Harga Pembelian Pemerintah (HPP), sedangkan kebijakan harga maksimum diatur pada kebijakan Harga Eceran Tertinggi (HET) (Achsani, 2009).

HET Beras diatur pada Peraturan Menteri Perdagangan No. 57/M-DAG/PER/8/2017 tentang Penetapan Harga Eceran Tertinggi Beras. Setiap wilayah di Indonesia memiliki harga acuan tertinggi dalam menjual beras. Peraturan ini mengatur dua jenis beras, yaitu beras premium dan medium. Harga eceran tertinggi di wilayah Sulawesi adalah Rp $12.800 / \mathrm{kg}$ untuk beras jenis premium dan Rp 9.450/ kg untuk beras jenis medium (Azwar, 2016).

Sulawesi Selatan dikenal sebagai daerah penghasil beras dan salah satu pemasok utama beras di Indonesia. Namun, beras masih menjadi salah satu komoditas penyumbang inflasi di Sulawesi Selatan secara year-on-year. Hal ini ditunjukkan dari angka andil inflasi di 5 kota inflasi untuk Sulawesi Selatan: Kota Makassar, Kota Pare-pare, Kabupaten Bone, Kota Palopo, dan Kabupaten Bulukumba.

Tujuan dari penelitian ini adalah untuk mengetahui seberapa signifikannya kebijakan ini memengaruhi laju inflasi di Sulawesi Selatan. Penelitian ini mengambil 3 dari 5 kota/kabupaten acuan inflasi yang ditetapkan oleh Badan Pusat Statistik, yakni Kota Makassar, Kota Pare-pare, dan Kabupaten Bone. Alasan mendasarnya adalah ketiga daerah tersebut merupakan tiga daerah besar di Sulawesi Selatan serta jalur distribusi beras ke wilayah-wilayah lain di Indonesia. Metode penelitian yang digunakan adalah regresi linier berganda dengan satu variabel terikat dan empat variabel bebas.

\section{Metode Penelitian}

Sumber data yang diambil pada penelitian ini berasal dari beragam sumber, yang kemudian disebut data sekunder. Data-data sekunder ini diambil dari Badan Pusat Statistik, Badan Ketahanan Pangan Kementerian Pertanian RI, Food and Agriculture Organization (FAO), serta Bank Indonesia.

Regresi linier berganda merupakan alat analisis yang digunakan pada penelitian ini. Analisis ini berguna dalam mengetahui hubungan variabel-variabel bebas terhadap variabel terikatnya. Variabel terikat yang digunakan adalah laju inflasi secara year-on-year. Variabelvariabel bebas yang digunakan yaitu pasokan beras $\left(X_{1}\right)$, margin harga beras $\left(X_{2}\right)$, nilai tukar riil (RER) $\left(X_{3}\right)$, dan variabel dummy. Variabel dummy bertujuan untuk mengidentifikasi apakah terdapat perubahan setelah kebijakan HET ditetapkan pada bulan September 2017. Maka, persamaan regresi linier berganda yang digunakan adalah sebagai berikut.

$$
\text { INFberas }=\beta o+\beta 1 X 1+\beta 2 X 2+\beta 3 X 3+\beta 4 \text { Dummy }
$$

Keterangan:

$\beta o, \beta 1, \beta 2, \beta 3, \beta 4$

$\mathrm{X} 1$

$\mathrm{X} 2$
$=$ koefisien masing-masing variabel;

$=$ pasokan beras $(\mathrm{kg})$;

$=$ margin harga beras $(\mathrm{Rp} / \mathrm{kg})$; 
$\mathrm{X} 3$

Dummy
= nilai tukar riil (RER) (rasio);

= variabel boneka dengan nilai 0 (sebelum) dan 1 (sesudah).

Persamaan tersebut di atas merupakan persamaan yang menggunakan satuan yang berbeda masing-masing variabelnya. Oleh karena itu menurut Gujarati (2003), pemilihan model persamaan ini didasarkan pada penggunaan model logaritma natural (Ln) yang memiliki keuntungan, yaitu meminimalkan kemungkinan terjadinya heteroskedastisitas. Persamaan setelah digunkannya logaritma natural sebagai langkah transformasi data adalah sebagai berikut.

$$
\text { INFberas }=\beta o+\beta 1 \ln X 1+\beta 2 \ln X 2+\beta 3 \ln X 3+\beta 4 D u m m y
$$

Berdasarkan persamaan tersebut, maka kerangka pemikiran dari penelitian ini adalah sebagai berikut.

\section{Gambar 1. Kerangka Pemikiran}

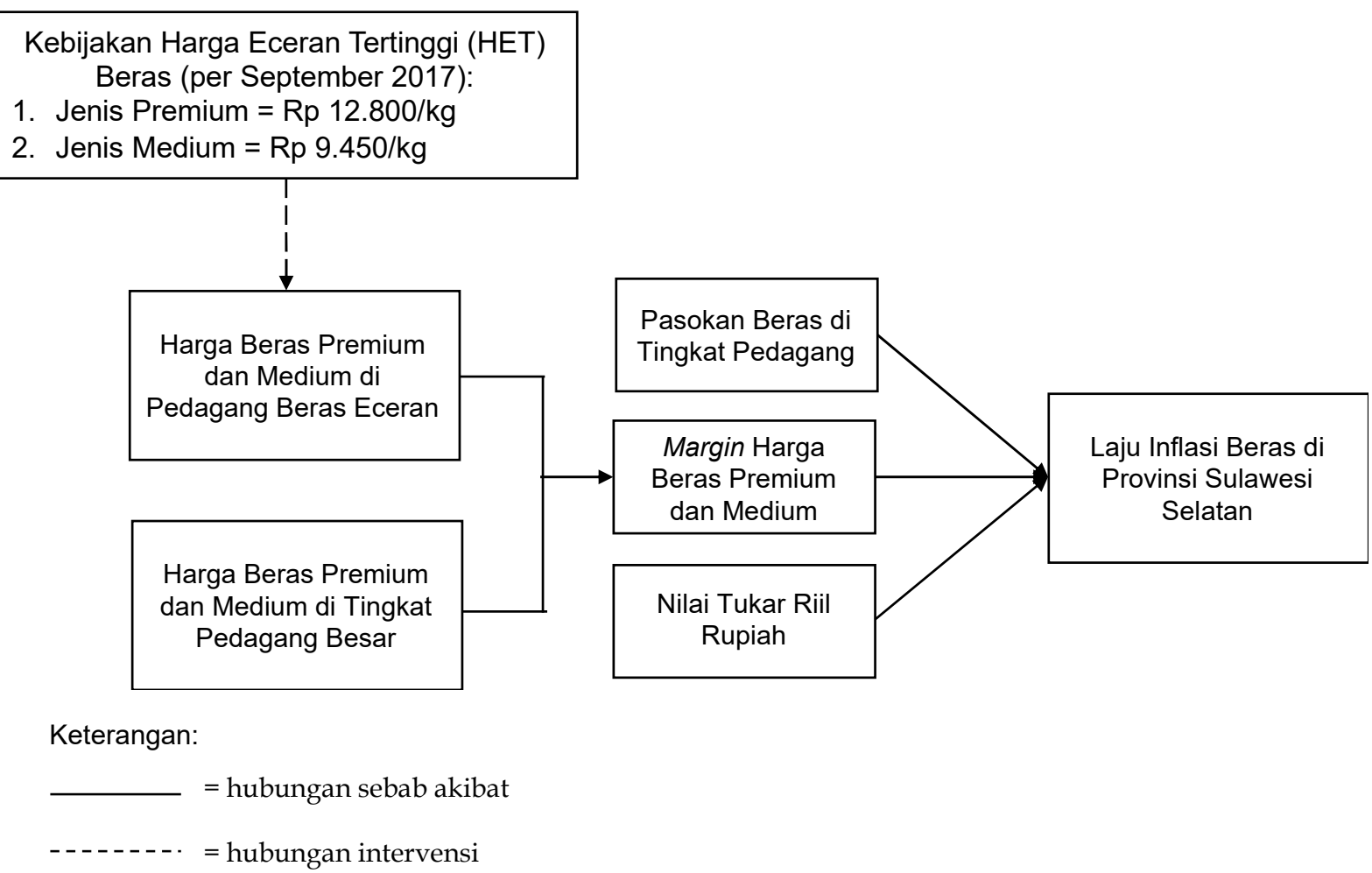

\section{Hasil dan Pembahasan}

\subsection{Perubahan Margin Harga Beras, Pasokan Beras, dan Nilai Tukar Riil}

Perubahan yang terjadi pada ketiga variabel perlu dilihat sebagai tolok ukur pengambilan kesimpulan pada penelitian ini. Data margin harga beras dihitung dan dikelompokkan secara rata-rata sebelum dan sesudah penetapan kebijakan HET diberlakukan. Data persentase rata-rata tersebut kemudian diuji untuk diketahui tingkat signifikansinya menggunakan uji paired sample T. Berdasarkan data yang telah dikumpulkan, perubahan margin harga beras di ketiga daerah telah disajikan pada Tabel 1 pada halaman berikut. 
Tabel 1.

Persentase Rata-rata Margin Harga Beras (\%).

\begin{tabular}{|c|c|c|c|}
\hline $\begin{array}{c}\text { Margin Harga } \\
\text { Beras }\end{array}$ & $\begin{array}{c}\text { Sebelum Penetapan } \\
\text { HET Beras } \\
\text { April } 2016 \text { - Agustus } \\
2017\end{array}$ & $\begin{array}{c}\text { Sesudah Penetapan HET } \\
\text { Beras } \\
\text { September } 2017 \text { - Desember } \\
2018\end{array}$ & Uji Sig. T \\
\hline \multicolumn{4}{|l|}{ Kota Makassar } \\
\hline Medium & $2,65 \%$ & $7,04 \%$ & $0,000^{*}$ \\
\hline Premium & $9,62 \%$ & $12,08 \%$ & 0,161 \\
\hline \multicolumn{4}{|l|}{ Kota Pare-pare } \\
\hline Medium & $5,94 \%$ & $5,63 \%$ & 0,592 \\
\hline Premium & $3,09 \%$ & $2,56 \%$ & 0,410 \\
\hline \multicolumn{4}{|l|}{ Kabupaten Bone } \\
\hline Medium & $3,57 \%$ & $1,55 \%$ & $0,000^{*}$ \\
\hline Premium & $3,91 \%$ & $4,87 \%$ & $0,010^{*}$ \\
\hline
\end{tabular}

Keterangan: * merupakan Uji Paired Sample T yang bernilai signifikan $<\alpha=0,05$.

Sumber: Data Sekunder yang telah diolah, 2019.

Pada Tabel 1, rata-rata persentase dihitung berdasarkan periode sebelum dan setelah penetapan HET Beras. Nilai uji $\mathrm{T}$ yang signifikan menunjukkan adanya pengaruh HET terhadap naik atau turunnya persentase margin harga beras. Hasil tersebut menunjukkan Kota Makassar dan Kabupaten Bone dengan beras jenis premium yang persentase margin harganya meningkat setelah ditetapkannya HET. Menurut Azwar (2018), hal ini disebabkan oleh panjangnya rantai distribusi yang menyebabkan selisih harga semakin besar di Kota Makassar. Adapun untuk Kabupaten Bone margin harga beras jenis medium mengalami penurunan disebabkan oleh penyerapan beras semakin baik, untuk beras jenis medium sesuai dengan pernyataan Ibrahim (2018). Rata-rata pasokan beras di ketiga tempat penelitian telah disajikan pada Tabel 2 di bawah ini.

Tabel 2.

Rata-rata Pasokan Beras (Kg).

\begin{tabular}{|c|c|c|}
\hline $\begin{array}{c}\text { Pasokan } \\
\text { Beras }\end{array}$ & $\frac{\text { Sebelum Penetapan HET Beras }}{\text { April } 2016 \text { - Agustus } 2017}$ & $\frac{\text { Sesudah Penetapan HET Beras }}{\text { September } 2017 \text { - Desember } 2018}$ \\
\hline Kota Makassar & & \\
\hline Medium & 8769,82 & 5202,62 \\
\hline $\begin{array}{l}\text { Premium } \\
\text { Kota Pare-pare }\end{array}$ & 6212,05 & 5721,31 \\
\hline Medium & 2065,88 & 775,62 \\
\hline $\begin{array}{l}\text { Premium } \\
\text { Kabupaten Bone }\end{array}$ & 1273,65 & 482,19 \\
\hline Medium & 2690,60 & 3528,12 \\
\hline Premium & 1672,53 & 3412,50 \\
\hline
\end{tabular}

Sumber: Data Sekunder yang telah diolah, 2019. 
Pada Tabel 2 dapat dilihat rata-rata pasokan beras yang disuplai ke tingkat pedagang untuk tiap periode yang ditentukan pada tabel. Suplai beras terlihat meningkat pada Kabupaten Bone, baik untuk beras jenis medium maupun premium. Menurut Ibrahim (2018), hal ini disebabkan oleh penyerapan beras oleh Bulog dari penggilingan yang lebih besar dan surplus produksi beras.

Sedangkan di kedua daerah, yaitu Kota Makassar dan Kota Pare-pare, menurut Susilowati (2018) pasokan beras menurun disebabkan produksi beras yang defisit serta kedua daerah merupakan pangsa pengiriman beras terbesar ke daerah lain di Indonesia. Adapun rata-rata nilai tukar riil atau real exchange rate (RER) di ketiga daerah telah disajikan pada Tabel 3 berikut.

Tabel 3.

Rata-rata Rasio Nilai Tukar Riil (RER) Beras.

\begin{tabular}{lcc}
\hline \multicolumn{1}{c}{$\begin{array}{c}\text { Nilai Tukar Riil } \\
\text { (RER) }\end{array}$} & $\begin{array}{c}\text { Sebelum Penetapan HET Beras } \\
\text { April 2016 - Agustus 2017 }\end{array}$ & $\begin{array}{c}\text { Sesudah Penetapan HET Beras } \\
\text { September 2017 - Desember 2018 }\end{array}$ \\
\hline $\begin{array}{l}\text { Kota Makassar } \\
\text { Medium }\end{array}$ & 1,94 & 1,78 \\
Premium & 2,27 & 2,02 \\
Kota Pare-pare & & \\
Medium & 1,79 & 1,55 \\
Premium & 2,11 & 1,88 \\
Kabupaten Bone & & 1,55 \\
Medium & 1,78 & 1,89 \\
Premium & 2,03 & \\
\hline
\end{tabular}

Sumber: Data Sekunder yang telah diolah, 2019.

Pada Tabel 3, rata-rata nilai tukar riil menunjukkan rasio yang menurun setelah penetapan kebijakan HET ditetapkan. Hal ini dikarenakan nilai tukar riil sangat bergantung pada nilai tukar rupiah pada periode yang dihitung, harga beras domestik meningkat, serta harga beras internasional juga turut meningkat per Juni 2017. Hal ini disebabkan oleh pasokan beras di beberapa negara acuan seperti Thailand, Vietnam, dan India berkurang disebabkan tingginya permintaan beras dari Iran dan Bangladesh. Oleh karena itu, harga beras di negara tersebut naik dan juga turut memengaruhi harga beras pada skala internasional (FAO, 2017).

\subsection{Pengaruh Kebijakan HET Beras terhadap Laju Inflasi di Sulawesi Selatan}

Mengetahui pengaruh kebijakan HET Beras terhadap laju inflasi di Sulawesi Selatan, pertama yang harus dilakukan adalah mengumpulkan data inflasi pada ketiga daerah yang diteliti. Uji asumsi klasik merupakan tahapan pertama yang harus diujikan pada semua variabel yang digunakan pada penelitian ini. Hasil dari uji asumsi klasi pada keenam sampel menyatakan bahwa variabel yang digunakan pada sampel layak untuk diestimasi. Uji asumsi klasik yang digunakan adalah uji normalitas, uji multikolinieritas, uji heteroskedastisitas, dan uji autokorelasi.

Langkah selanjutnya adalah mengidentifikasi level signifikan tiap variabel bebas terhadap variabel terikat menggunakan Uji R-Square, Uji T Parsial, dan Uji F. Maka dari keenam hasil penelitian, empat di antaranya menunjukkan adanya hubungan antara penetapan kebijakan HET Beras terhadap laju inflasi. Hubungan ini diasumsikan oleh dummy variable. Hasil penelitian ini dapat dilihat pada Tabel 4 pada halaman berikut. 
Tabel 4.

Pengaruh Kebijakan HET Beras terhadap Laju Inflasi di Sulawesi Selatan.

\begin{tabular}{|c|c|c|c|c|c|c|c|}
\hline \multirow{2}{*}{ Daerah } & \multicolumn{7}{|c|}{ Koefisien tiap Variabel } \\
\hline & Bo & X1 & $\mathrm{X} 2$ & $\mathrm{X} 3$ & $D$ & $\mathbf{F}$ & $\operatorname{Adj} . \mathbf{R}^{2}$ \\
\hline $\begin{array}{r}\text { Kota Makassar } \\
\bullet \quad \text { Medium }\end{array}$ & $\begin{array}{r}-0,175 \\
(0,343)\end{array}$ & $\begin{array}{r}0,047^{*} \\
(0,015)\end{array}$ & $\begin{array}{r}0,043^{*} \\
(0,046)\end{array}$ & $\begin{array}{r}-0,086 \\
(0,575)\end{array}$ & $\begin{array}{r}-0,001 \\
(0,968)\end{array}$ & $x$ & $17,3 \%$ \\
\hline - Premium & $\begin{array}{l}-0,380^{*} \\
(0,017)\end{array}$ & $\begin{array}{l}0,035^{*} \\
(0,003)\end{array}$ & $\begin{array}{r}0,032^{*} \\
(0,005)\end{array}$ & $\begin{array}{r}0,235 \\
(0,082)\end{array}$ & $\begin{array}{l}0,046^{*} \\
(0,033)\end{array}$ & $\sqrt{ }$ & $41.0 \%$ \\
\hline $\begin{array}{r}\text { Kota Pare-pare } \\
\bullet \quad \text { Medium }\end{array}$ & $\begin{array}{l}-0,260^{*} \\
(0,021)\end{array}$ & $\begin{array}{r}0,038^{*} \\
(0,016)\end{array}$ & $\begin{array}{r}0,018 \\
(0,303)\end{array}$ & $\begin{array}{r}-0,110 \\
(0,211)\end{array}$ & $\begin{array}{c}0,052^{*} \\
(0,005)\end{array}$ & $\sqrt{ }$ & $26.8 \%$ \\
\hline - Premium & $\begin{array}{r}0,084 \\
(0,351)\end{array}$ & $\begin{array}{r}0,013 \\
(0,162)\end{array}$ & $\begin{array}{r}0,024^{*} \\
(0,006)\end{array}$ & $\begin{array}{r}-0,090 \\
0,348\end{array}$ & $\begin{array}{l}0,033^{*} \\
(0,050)\end{array}$ & $\sqrt{ }$ & $27.7 \%$ \\
\hline $\begin{array}{c}\text { Kabupaten Bone } \\
-\quad \text { Medium }\end{array}$ & $\begin{array}{r}0,575 \\
(0,076)\end{array}$ & $\begin{array}{r}-0,021 \\
(0,593)\end{array}$ & $\begin{array}{r}0,075^{*} \\
(0,010)\end{array}$ & $\begin{array}{r}-0,276 \\
(0,149)\end{array}$ & $\begin{array}{r}0,067 \\
(0,055)\end{array}$ & $\sqrt{ }$ & $37.9 \%$ \\
\hline - Premium & $\begin{array}{r}1,082^{*} \\
(0,001) \\
\end{array}$ & $\begin{array}{l}-0,102^{*} \\
(0,001)\end{array}$ & $\begin{array}{r}0,011 \\
(0,514) \\
\end{array}$ & $\begin{array}{l}-0,538^{*} \\
(0,008)\end{array}$ & $\begin{array}{r}0,092^{*} \\
(0,006)\end{array}$ & $\sqrt{ }$ & $49.8 \%$ \\
\hline
\end{tabular}

Keterangan: * merupakan koefisien pada variabel yang bernilai signifikan $<\alpha=0,05$.

Sumber: Data Sekunder yang telah diolah, 2019.

Pada Tabel 4, persamaan regresi linier yang berpengaruh signifikan dapat dilihat pada nilai signifikansi tiap variabel yang diberikan tanda kurung. Adapun penjelasan dari masing-masing daerah adalah sebagai berikut.

\section{a. Kota Makassar}

Persamaan regresi linier berganda yang secara simultan (Uji F) signifikan pada level lebih kecil daripada $\alpha=0,05$ adalah persamaan regresi linier berganda dengan sampel beras jenis premium. Uji Adjusted $R^{2}$ bagi persamaan ini bernilai $41 \%$. Hal ini berarti variabel bebas yang digunakan pada persamaan ini dapat menjelaskan hubungannya terhadap laju inflasi sebesar $41 \%$. Selain itu, 59\% $(100 \%-41 \%=59 \%)$ lainnya mampu dijelaskan oleh variabel lain yang tidak dimasukkan pada penelitian ini. Adapun Uji Parsial masing-masing variabel bebas dari persamaan ini adalah sebagai berikut.

i) Konstanta ( $\beta 0)$

Konstanta persamaan ini bernilai $-0,380$ dan signifikan pada level di bawah 0,05 . Hal ini berarti jika variabel-variabel bebas lainnya diabaikan, maka laju inflasi di Kota Makassar untuk beras jenis premium sebesar $-0,380 \%$.

ii) Pasokan Beras (X1)

Koefisien variabel pasokan beras adalah 0,035 dan signifikan pada level di bawah 0,05. Hal ini tidak sesuai dengan penelitian oleh Syamsurijal (2008) yang menyatakan bahwa koefisien pasokan beras harusnya bertanda negatif; pasokan beras memiliki hubungan yang negatif terhadap laju inflasi. Artinya, jika inflasi meningkat apabila pasokan beras ditambah, maka laju inflasi akan melambat. Namun, hasil penelitian ini mengindikasikan bahwa tingkat 
konsumsi beras di Kota Makassar masih lebih tinggi dibandingkan pasokan beras yang tersedia.

\section{iii) Margin Harga Beras (X2)}

Koefisien margin harga beras bernilai 0,032 dan signifikan pada level di bawah 0,05. Hal ini sesuai dengan pendapat Azwar (2018), harga beras memiliki pengaruh terhadap laju inflasi disebabkan oleh panjangnya rantai distribusi sehingga margin harga akan ikut terpengaruh.

\section{iv) Variabel Dummy}

Koefisien variabel dummy bernilai 0,046 dan signifikan pada level di bawah 0,05 . Apabila nilai variabel dummy bernilai 1 (menggambarkan keadaan setelah kebijakan HET Beras ditetapkan), maka hasilnya adalah kebijakan dummy yang bernilai positif memiliki hubungan terhadap peningkatan laju inflasi di Kota Makassar untuk beras jenis premium.

\section{b. Kota Pare-pare}

Persamaan regresi linier berganda yang secara simultan (Uji F) signifikan pada level lebih kecil daripada $\alpha=0,05$ adalah persamaan regresi linier berganda dengan sampel beras jenis medium dan premium. Uji Adjusted $R^{2}$ bagi persamaan dengan beras jenis medium bernilai $26,8 \%$. Sedangkan, uji Adjusted $R^{2}$ bagi persamaan dengan beras jenis premium bernilai $27,7 \%$.

Persentase Adjusted $R^{2}$ menjelaskan bahwa variabel bebas yang digunakan pada persamaan regresi linier berganda pada beras jenis medium dapat menjelaskan hubungannya terhadap laju inflasi sebesar $26,8 \%$. Selebihnya, yaitu sebesar $73,2 \%$ lainnya mampu dijelaskan oleh variabel lain yang tidak dimasukkan pada penelitian ini. Sedangkan, variabel bebas yang digunakan pada persamaan regresi linier berganda pada beras jenis premium dapat menjelaskan hubungannya terhadap laju inflasi sebesar $27,7 \%$. Selebihnya, yaitu sebesar 72,3\% lainnya mampu dijelaskan oleh variabel lain yang tidak dimasukkan pada penelitian ini. Adapun Uji Parsial atau Uji T masing-masing variabel bebas dari persamaan ini adalah sebagai berikut.

i)

\section{Konstanta ( $\beta$ o)}

Konstanta persamaan beras jenis medium adalah sebesar -0,260. Hal ini menunjukkan bahwa apabila variabel lain diabaikan, maka laju inflasi Kota Pare-pare untuk beras jenis medium sebesar $-0,260 \%$. Sedangkan, konstanta untuk persamaan beras jenis premium tidak signifikan pada level di bawah dari 0,05 .

\section{ii) Pasokan Beras (X1)}

Koefisien variabel pasokan beras jenis medium adalah 0,038 dan signifikan pada level di bawah 0,05. Hal ini tidak sesuai dengan penelitian oleh Syamsurijal (2008) yang menyatakan bahwa koefisien pasokan beras harusnya bertanda negatif; pasokan beras memiliki hubungan yang negatif terhadap laju inflasi. Menurut Susilowati (2018), pasokan beras di Kota Pare-pare cukup rentan memengaruhi inflasi dikarenakan Kota Pare-pare merupakan pangsa pengiriman beras terbesar di Provinsi Sulawesi Selatan. Pasokan beras yang dijual di daerah tersebut tidak hanya untuk konsumsi masyarakatnya, melainkan juga dikirim ke daerah lain. Sedangkan, koefisien variabel pasokan beras untuk beras jenis premium tidak signifikan pada level di bawah 0,05. 
iii) Margin Harga Beras (X2)

Koefisien margin harga beras untuk beras jenis premium bernilai 0,024 dan signifikan pada level di bawah 0,05. Hal ini sesuai dengan pendapat Ade (2018), yang menyatakan bahwa margin harga dipengaruhi oleh harga di tingkat pedagang besar yang sebelumnya dipengaruhi oleh harga di tingkat penggilingan. Apabila harga di tingkat penggilingan naik, maka harga beras di Kota Pare-pare, khususnya di Pasar Lakessi akan ikut terpengaruh. Sedangkan, margin harga beras untuk beras jenis medium tidak berpengaruh signifikan terhadap laju inflasi pada level 0,05.

\section{iv) Variabel Dummy}

Kedua persamaan regresi linier berganda menunjukkan adanya hubungan antara laju inflasi dengan penetapan kebijakan HET Beras di Kota Pare-pare. Koefisien variabel dummy untuk persamaan regresi linier berganda jenis beras medium sebesar 0,052. Sedangkan, koefisien variabel dummy untuk persamaan regresi linier berganda jenis beras premium sebesar 0,033. Hal ini berarti bahwa apabila nilai variabel dummy bernilai 1 (menunjukkan keadaan setelah penetapan kebijakan HET Beras), maka secara positif akan memengaruhi laju inflasi di Kota Pare-pare; baik pada beras jenis medium maupun jenis premium. Hubungan yang positif tersebut terlihat pada koefisien variabel dummy yang bernilai positif.

\section{c. Kabupaten Bone}

Persamaan regresi linier berganda yang secara simultan (Uji F) signifikan pada level lebih kecil daripada $\alpha=0,05$ adalah persamaan regresi linier berganda dengan sampel beras jenis premium. Uji Adjusted $R^{2}$ bagi persamaan ini bernilai $49,8 \%$. Hal ini berarti variabel bebas yang digunakan pada persamaan ini dapat menjelaskan hubungannya terhadap laju inflasi sebesar $49,8 \%$. Selain itu, 50,2\% $(100 \%-49,8 \%=50,2 \%)$ lainnya mampu dijelaskan oleh variabel lain yang tidak dimasukkan pada penelitian ini. Adapun Uji Parsial atau Uji T masing-masing variabel bebas dari persamaan ini adalah sebagai berikut.

\section{i) Konstanta ( $\beta$ o)}

Konstanta persamaan ini bernilai 1,082 dan signifikan pada level di bawah 0,05. Hal ini berarti jika variabel-variabel bebas lainnya diabaikan, maka laju inflasi di Kabupaten Bone untuk beras jenis premium sebesar 1,082\%.

\section{ii) Pasokan Beras (X1)}

Koefisien variabel pasokan beras adalah -0,102 dan signifikan pada level di bawah 0,05. Hal ini sesuai dengan penelitian oleh Syamsurijal (2008) yang menyatakan bahwa koefisien pasokan beras harusnya bertanda negatif; pasokan beras memiliki hubungan yang negatif terhadap laju inflasi. Artinya, jika inflasi meningkat apabila pasokan beras ditambah, maka laju inflasi akan melambat. Menurut Ibrahim (2018), pasokan beras jenis premium di Kabupaten Bone cenderung didukung oleh total hasil panen yang melimpah dan dapat memenuhi kebutuhan masyarakatnya.

\section{iii) Nilai Tukar Riil/RER (X3)}

Koefisien nilai tukar riil rupiah bernilai negatif terhadap laju inflasi beras di Kabupaten Bone. Hal ini tidak sejalan dengan teori Marshall - Lerner yang menyatakan bahwa koefisien RER seharusnya bertanda positif. Artinya, jika nilai tukar riil meningkat maka akan berpengaruh terhadap peningkatan laju 
inflasi di daerah tersebut. Namun, hubungan negatif tersebut bisa saja terjadi karena analisis pada penelitian ini dibatasi hanya pada hubungan/pengaruh antara inflasi dengan nilai tukar riil tanpa memerhatikan variabel ekonomi lainnya seperti output gap, ekspektasi inflasi, dan lain-lain (Achsani, 2009).

\section{iv) Variabel Dummy}

Koefisien variabel dummy bernilai 0,092 dan signifikan pada level di bawah 0,05 . Apabila nilai variabel dummy bernilai 1 (menggambarkan keadaan setelah kebijakan HET Beras ditetapkan), maka hasilnya adalah kebijakan dummy yang bernilai positif memiliki hubungan terhadap peningkatan laju inflasi di Kabupaten Bone untuk beras jenis premium.

Tujuan pemerintah mengeluarkan kebijakan HET Beras secara umum adalah untuk menekan laju inflasi. Beras merupakan salah satu komoditas penyumbang inflasi. Namun, hasil penelitian ini menunjukkan sebaliknya. Kebijakan HET Beras justru menaikkan angka inflasi secara signifikan, terutama pada beras jenis premium. Hal ini sesuai dengan temuan Siahaan (2018), bahwa kebijakan HET Beras ini justru akan menjadi pemicu terjadinya transmisi harga vertikal yang tidak simetris. Akibatnya, harga di tingkat petani lebih murah dan tidak sesuai dengan harga yang ditetapkan pada HPP.

Keempat persamaan regresi linier berganda tersebut tiga di antaranya merupakan persamaan yang mengacu pada jenis beras premium (Kota Makassar, Kota Pare-pare, dan Kabupaten Bone). Hanya persamaan pertama pada sampel Kota Pare-pare merupakan beras jenis medium. Menurut Andri (2018), di masyarakat terjadi pergeseran preferensi dari beras medium menjadi beras premium. Hal ini juga dikemukakan oleh Maulida (2018), bahwa operasi pasar oleh Bulog akan lebih efektif jika menyertakan beras premium ke dalam kegiatan operasi pasar.

Kebijakan HET beras juga dianggap tidak tepat diterapkan di Provinsi Sulawesi Selatan. Hal ini dikarenakan harga beras di Provinsi Sulawesi Selatan tidak pernah memberatkan konsumen. Kemungkinan akan terjadi pergolakan pada harga beras dengan diberlakukannya kebijakan tersebut adalah pada saat anomali cuaca yang menyebabkan petani tidak bisa memanen. Hal tersebut akan menyebabkan pergolakan harga, namun harga beras dibatasi oleh kebijakan HET, maka petani ditakutkan akan menanggung kerugian yang tidak sedikit (Abdullah, 2017).

\section{Kesimpulan dan Saran}

Kesimpulan yang dapat diambil pada penelitian ini adalah dari 6 hasil penelitian yang diambil dari 3 kota/kabupaten di Provinsi Sulawesi Selatan, 4 di antaranya mampu menjelaskan bahwa terdapat pengaruh yang signifikan oleh kebijakan HET Beras terhadap laju inflasi beras. Kebijakan tersebut justru membuat angka laju inflasi beras meningkat. Beras masuk pada kategori volatile food, pemerintah dirasa perlu mengaji ulang kebijakan ini. Alasannya adalah beras merupakan komoditas pertanian yang diproduksi secara massal. HET biasanya digunakan pada produk di luar produk pertanian. Asumsi harga eceran tertinggi lebih cocok diberlakukan untuk komoditas pada kategori administered price seperti BBM.

Selain itu, nilai Adjusted $R^{2}$ dianggap masih belum kuat menjelaskan pengaruh variabel bebas yang diujikan pada penelitian ini terhadap laju inflasi. Ke depannya, penelitian dengan topik serupa diharapkan mampu menyempurnakan penelitian ini dan lebih banyak 
lagi penelitian dengan topik serupa untuk membantu pemerintah dalam mengatasi polemik harga beras.

\section{Daftar Pustaka}

Abdullah, A., 2017. Penetapan HET Beras Tidak Cocok di Sulsel. http:/ / rakyatsulsel.com/penetapan-het-beras-tidak-cocok-di-sulsel.html, diakses pada hari Senin, 21 Januari 2019 di Makassar.

Achsani, N. A., 2009. Keterkaitan Inflasi dengan Nilai Tukar Riil: Analisis Komparatif Antara ASEAN+3, Uni Eropa, dan Amerika Utara. https://ejournal.unair.ac.id/JEBA/article/view/4240, diakses pada hari Rabu, 30 Januari 2019 di Makassar.

Ade. 2018. Harga Beras Melonjak, Ini Penyebabnya. http:/ / parepos.fajar.co.id/2018/01/harga-beras-melonjak-ini-penyebabnya/, diakses pada hari Senin, 28 Januari 2019 di Makassar.

Andri, Yustinus. 2018. Operasi Beras Harus Dirombak, Masyarakat Lebih Suka Beras Premium Bawah. https://ekonomi.bisnis.com/read/20180925/99/841847/operasiberas-harus-dirombak-masyarakat-lebih-suka-beras-premium, diakses pada hari Rabu, 24 Januari 2019 di Makassar.

Azwar, 2016. Harga Beras di Makassar Sudah Rp 280 Ribu Satu Karung. https:/ / celebesonline.com/2016/12/24/55080/harga-beras-di-makassarsudah-rp-280-ribu-satu-karung/, diakses pada hari Senin 21 Januari 2019 di Makassar.

Badan Pusat Statistik. 2017. Konsumsi Beras di Indonesia. https://databoks.katadata.co.id/datapublish/2018/01/12/inilah-perbandinganproduksi-dan-konsumsi-beras-nasional, diakses pada hari Minggu, 4 November 2018 di Makassar.

Food and Agricultural Organization (FAO). 2017. Food Price Monitoring and Analysis: International Rice Prices Continued to Increase in June. http://www.fao.org/giews/food-prices/internationalprices/detail/en/c/992158/, diakses pada hari Sabtu, 2 Februari 2019 di Makassar.

Ghozali, Imam. 2013. Aplikasi Analisis Multivariate dengan Program SPSS: Edisi Ketujuh. Semarang: Badan Penerbit Universitas Diponegoro.

Gujarati, Damodar. 2003. Basic Econometrics. New York: McGraw-Hill.

Ibrahim. Supriadi. 2018. Stok Beras di Kabupaten Bone Aman Hingga Akhir 2018. https:/ / makassar.sindonews.com/read/3829/4/stok-beras-di-kabupatenbone-aman-hingga-akhir-2018-1516010501, diakses pada hari Senin, 29 Januari 2019 di Makassar.

Maulida, Annisa. 2018. Konsumsi Masyarakat Mulai Bergeser ke Beras Premium. https://industri.kontan.co.id/news/konsumsi-masyarakat-mulai-bergeserke-beras-premium, diakses pada hari Senin, 21 Januari 2019 di Makassar. 
Santoso, Singgih. 2000. SPSS: Buku Latihan Statistik Parametrik. Jakarta: Elex Media Komputindo.

Siahaan, David Michael. 2018. Analisis Variasi Harga Beras di Tingkat Petani dengan Penetapan Harga Eceran Tertinggi (HET) Beras (Kasus: Desa Melati II, Kecamatan Perbaungan, Kabupaten Serdang Bedagai). Medan: Universitas Sumatera Utara.

Susilowati, Sri H. 2018. Perdagangan Antarpulau Beras di Provinsi Sulawesi Selatan. http://ejurnal.litbang.pertanian.go.id/index.php/akp/article/view/8507, diakses pada hari Minggu, 27 Januari 2019 di Makassar.

Syamsurijal. 2008. Pengaruh Produksi Beras, Stock Beras Dan Infrastruktur Jalan Dan Jembatan Terhadap Inflasi Di Sumatera Selatan. Palembang: Prodi Ekonomi Pembangunan, Fakultas Ekonomi Universitas Sriwijaya, Provinsi Sumatera Selatan. 